\title{
MANCHESTER
}

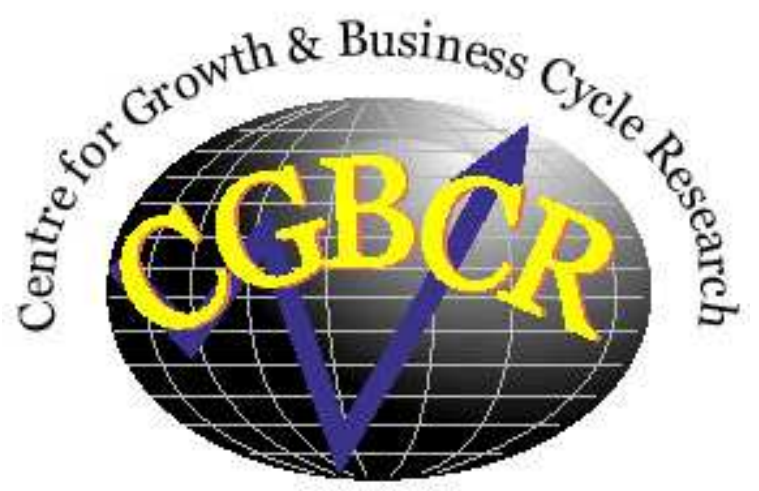

Discussion Paper Series

\section{Macro-institutional Instability and the Incentive to Innovate}

By

\section{Serena Masino}

Centre for Growth and Business Cycle Research, Economic Studies,

University of Manchester, Manchester, M13 9PL, UK

May 2012

Number 167

Download paper from:

http://www.socialsciences.manchester.ac.uk/cgbcr/discussionpape rs/index.html 


\title{
MACRO-INSTITUTIONAL INSTABILITY AND THE INCENTIVE TO INNOVATE
}

\author{
Serena Masino ${ }^{1}$ \\ University of Manchester and CGBCR \\ serena.masino@manchester.ac.uk
}

\begin{abstract}
This paper investigates the channels through which macroeconomic and institutional instability prevents or hinders innovative investment undertakings financed by the domestic private sector. The analysis is based on a sample of 44 countries representing all levels of development and considers a number of instability dimensions. The results suggest a negative impact of real, monetary and political instability on the aggregate level of national R\&D financed by the business sector. Thus, they highlight the desirability of stable macroinstitutional environments in preventing avoidance or abandonment of private innovation undertakings.
\end{abstract}

Keywords: Macroeconomic Volatility, Political Instability, Private R\&D Investment, Innovation. JEL Classification: C33, O11, O31, O33

\section{INTRODUCTION}

The importance of private innovation for growth is widely studied and recognised in the economic growth literature (Romer, 1990; Grossman and Helpman, 1993). However, pronounced disparities persist in the shares of private R\&D investment across countries. Figure 1 below may help gauge the extent of the cross-country disparity existing in private sectors' R\&D engagement, within the panel of economies used in this study. A number of structural factors have been investigated at length and proposed by the literature to explain the variation in countries' levels of private R\&D spending.

\footnotetext{
${ }^{1}$ I am grateful to Kyriakos Neanidis, Edmund Amann, David Chivers, participants to the 16th ICMAIF and to the Manchester University Development Economics Seminar (2012) for helpful discussion and comments. I bear sole responsibility, however, for the views expressed here.
} 
Figure 1. Business R\&D (\%GDP)

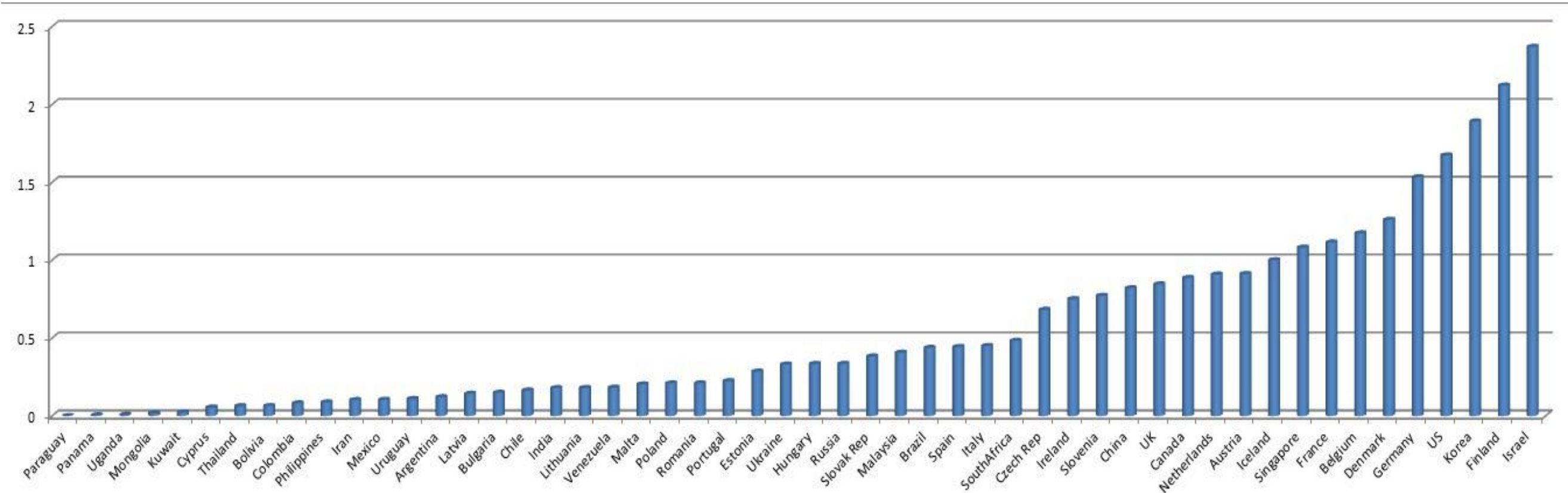

The values represent the ratio of Business Funded $R \& D$ to GDP, and they are calculated as a national average over the time span 1994-2008 (Raw data is from the OECD, Main Science \&Technology Database, UNESCO UIS and RICYT.org) 
This paper seeks to analyse such issue by focusing specifically on the impact that macroeconomic and political instability has on the level of aggregate private innovative investment. The reason for considering such perspective is related to the inherently high risk content of $R \& D$ investment, which is due to both its longer than average maturity horizon and to its high budget requirements (Katz, 1987). Based on these elements, it seemed plausible to hypothesise that firms' plans to spend on costly and risky innovative projects may be subject to revision in uncertain environments and that, as a result, aggregate private innovation spending may remain low or decline. Such hypothesis is supported by the findings of the empirical analysis presented in what follows, for the country panel considered.

This has been shown to be the result of firms' abandonment or avoidance of innovative investment undertakings by a number of microeconomic studies (Rafferty, 2003; Rafferty and Funk, 2008; Aghion et al, 2008; Bohva-Padilla et al, 2009, Aghion et al, 2010). The key contribution of this literature lies in the evidence provided to establish the existence of a cash-flow effect, which financially constrains firms and hinders the undertaking of innovative investment during downturns. Following the Schumpeterian analysis of the business cycle and Hall's reorganizational capital theory (1991), Saint-Paul (1993) had argued against such 'cash-flow' effect. He maintained that during recessions the opportunity cost faced by innovating firms in terms of foregone profits is lower as the value of expected sales decreases. This will provide an incentive for firms to allocate resources to $R \& D$ during recessionary phases.

Subsequently, however, Aghion and Saint-Paul (1998) revised this hypothesis and proved that it only holds as long as innovation costs are not so high as to represent a financial constraint. Along the same line of argument, Aghion et al. (2008) and Rafferty and Funk (2008) have shown that the existence of an asymmetry in binding constraints causes cash-flow effects to bind more during 
recessions than expansions. The result is that during recessions firms disinvest more than what they invest during expansions. Likewise, the 'opportunity-cost' effect is shown to bind more during booms than slumps. As a result, firms tend to relocate resources away from $R \& D$ and towards sales when positive demand shocks occur, but the opposite is unlikely to happen to the same extent during negative demand shocks. In addition, Bohva-Padilla et al. (2009) show that countercyclicality in R\&D spending is more likely in small and medium-sized firms, which tend to experience binding credit constraints the most; whereas, pro-cyclicality is more likely for noncredit constrained firms, such as MNCs or subsidised firms.

This paper represents a contribution to the existing literature on volatility and innovation in a few respects. Firstly, the literature described above concentrates on the first moment of the business cycle and in particular on the relationship between uncertainty surrounding recession expectations and firms' innovative behavior. This study, instead, extends the focus to the second moment of aggregate economies' fluctuations, that is, to overall volatility. Secondly, all the previously cited studies take up a microeconometric empirical approach and use firm-level data, most often on OECD-based firms only. This is typically due to the scarcity of developing countries' aggregate data on innovation (Goel and Ram, 1999; Aghion et al., 2010; Agénor and Neanidis, 2011). The present study adopts, instead, a macroeconometric approach and analyses cross-country variations in the level of national private $\mathrm{R} \& \mathrm{D}$. This is done in an attempt to uncover aggregate response patterns to macro-institutional instability which go beyond individual productive sectors' reactions.

A final contribution is represented by the estimation of separate impacts for various subcomponents forming aggregate volatility. This allows to disentangle a number of contemporaneous yet different dimensions co-existing in unstable macro-institutional environments. Specifically, my econometric findings suggest three ways in which instability negatively affects business R\&D 
spending, that is, political, real and monetary volatility. Such impacts will be shown to exhibit nonlinearities and to be larger for higher values of the real and monetary volatility dimensions. In addition, the negative effect of monetary instability appears to be mitigated during expansionary phases of the cycle, in the sample considered. Finally, the evidence surrounding both financial and international volatility is inconclusive. The remaining of the paper is structured in this way: the following section describes the model and the data used in the empirical analysis. The results, along with the sensitivity analysis, are presented in section 3 and 4 . Section 5 summarise the main findings and concludes. Finally, all data sources, the list of countries included in my sample and some methodological considerations appear in Appendix A and B.

\section{DATA AND MODEL}

The panel used for this analysis covers 15 years, from 1994 to 2008, while the baseline sample includes 956 observations. Due to missing data, however, the actual estimated panel size is reduced to 44 countries and 281 observations. Unfortunately, as it has been mentioned above, the limitations of aggregate innovation data is its scarcity. ${ }^{2}$ Sub-Saharan African countries, for example, with the exclusion of Uganda and South Africa, do not publish secondary data on innovation. Therefore, the panel suffers from an underrepresentation of African countries that

\footnotetext{
${ }^{2}$ To maximize the amount of data on public and private R\&D in the dataset, a number of databases have been merged which report measures of business and government R\&D for different countries (see Appendix A). Prior to this, lack of correspondence in measurement units as well as data discrepancies proved to be an issue. This has been overcome by rebasing all observations in the currency denomination year of the database containing the biggest portion of usable data. The unit of measurement has been homogenized across the various sources and million dollars have been used as the base unit. Finally, in a number of occasions, variables which were identically defined across the datasets differed in practice in the information and/or data used in their construction. Where such data discrepancies were encountered, appropriate transformations were used to restore comparability.
} 
needs to be acknowledged. The choice of regressors included in the model specification has taken into account and sought comparison with a variety of stability/instability indicators used in the literature, and it includes various control variables which have been used by the literature on the determinants of innovative investment. The benchmark econometric specification is as follows:

$$
y_{i t}=a_{i}+\sum_{j=1}^{m} \beta_{j} X_{j, i t}+\sum_{k=1}^{n} \gamma_{k} Z_{k, i t}+\sum_{l=1}^{q} \theta_{l} V_{l, i t}+\varepsilon_{i t}
$$

where the dependent variable, $y_{i t}$, is Business $\& D$ : the share of investment in R\&D financed by the domestic business sector, calculated as a \% of GDP. The right hand side of the regression includes three variable vectors, alongside a vector of time-invariant country fixed effects, $\alpha_{i \cdot}{ }^{3}$ The set $\left\{X_{j, i t}\right\}_{j=1}^{m}$ and $\left\{Z_{k, i t}\right\}_{k=1}^{n}$ contain, respectively, endogenous and exogenous control variables commonly used in the literature surrounding the determinants of R\&D investment.

Specifically, the following variables enter $\left\{X_{j, i t}\right\}_{j=1}^{m}$ : GDP per capita (in log-form) controls for the overall level of development of the countries in the panel. ${ }^{4}$ To capture a potential non-linearity in the relationship between level of development and private innovative spending, an interaction of GDP per capita with a dummy variable $(H I)$ has also been included. The dummy takes the value of 1 for countries classified as middle to high income economies by the World Bank's Atlas

3 A vector of time-varying common effects is also included in the benchmark specification (column 11 of Table 1) but none enters the regressions significantly, therefore time dummies are dropped from all subsequent estimations

${ }^{4}$ The relevance of human capital and educational levels for the innovation process has been highlighted by both theory (Lucas, 1988; Mankiw, Romer and Weil, 1992; Acemoglu and Zilibotti, 2001) and empirics (Wang, 2010). The reason why such variable is excluded from this analysis is because of its very high correlation with GDP. 
classification system and zero otherwise..$^{5}$ The share of publicly financed R\&D is used to capture the role of public investment tangible and intangible infrastructure, which may have a complementary or crowding out effect on private innovative investment (see David et al., 2000, for a review of the contrasting literature on this). Finally, this vector also contains a measure of trade openness calculated as the sum of exports and imports to GDP. Trade openness has been used by the literature (Smolny, 2003; Sameti et al., 2010) to capture the contribution that international exchange is likely to have on the ease and pace of innovation and technological progress.

The real interest rate appears among the exogenous control set $\left\{Z_{k, i t}\right\}_{k=1}^{n}$, alongside, a measure of stock market capitalization. The latter has been used in a number of studies to proxy for financial development; but it also captures the effect of higher levels of both credit availability and risk diversification accessible to the business sector (see David et al., 200 and Levine and Zervos, 1996, for a review). In addition, a measure of property rights protection is also included to reflect the importance this variable is believed to play in explaining the pace of innovation ((Yang and Maskus, 2001; Varsakelis; 2001; Lin et al., 2010). This is a composite index with values ranging from 0 to 10 , where 10 indicates the highest degree of rule of law enforcement. The impact measured by this variable is not limited to that of property right security, but it encompasses a more composite dimension of fairness and effectiveness in justice administration. Finally, as a component of government expenditure appears in the model (public R\&D) a measure of overall government's deficit/surplus to GDP is also included. This is done in order to achieve a consistent specification of the public budget constraint (see Bose et al., 2007; Katsimi and Sarantides, 2012,

\footnotetext{
${ }^{5}$ The non-linearity hypothesis has appeared as an interesting one to test after visual inspection of the scatterplot of GDP per capita against BusinessR\&D. In the plot, a positive relationship between overall level of development and business R\&D sets in only after a certain income threshold. Such threshold corresponds to the level of income classified as 'high' by the World Bank's Atlas classification (see Appendix A for a list of all high-income countries appearing in the sample).
} 
for details). At the same time, though, this variable proxies for the quality of public account management. While, strictly speaking the latter is not a standard indicator of instability, it does provide a measure of fiscal reliability, and it has been used by other studies in the same way (Fisher, 1993; Burnside and Dollar, 2000). Thus, its coefficient may partly capture the effect of more stable environments on private innovation.

The third vector $\left\{V_{l, i t}\right\}_{l=1}^{q}$ is composed by the indicators of instability, which impact is the object of this analysis. The Polity IV 'State Fragility Index' is used as an indicator of political and institutional stability. The index rates countries according to the fragility of their effectiveness and legitimacy, in four performance dimensions: security, policy, economics, and social cohesion. A country's fragility is measured by this Index as a state's capacity to manage conflict, make and implement public policy, deliver essential services, maintain system cohesion and quality of life. Institutional uncertainty affects many elements of the macroeconomic business environment: via, for example, failing policy commitments; switching tax and incentive regimes; or revised economic targets and priorities (Fosu, 1992; Alesina et al., 1996). Thereby, institutional instability can bring about a more or less abrupt alteration in investment profitability expectations. Real, financial and monetary volatility is represented, respectively, by the coefficient of variation of (log) GDP per capita, stock market capitalisation, and real interest rate. ${ }^{6}$ Recurrent fluctuations in output proxy for the instability in the overall level of savings and aggregate demand; whereas variability in stock market capitalisation rates or in lending interest rates influence the cost of capital. In view of the long-term maturity horizon characterizing innovative investment and of its high-budget, risky nature; the present analysis seeks to test whether aggregate levels of private spending in $R \& D$ decline as a consequence of excessive variability in expected return rates resulting from fluctuations in any of the aforementioned dimensions.

\footnotetext{
${ }^{6}$ Technical details on the construction of the volatility indicators can be found in Appendix B.
} 
The model is, first, estimated using a simple within-group estimator, which takes care of timeinvariant country specific fixed effects. Subsequently, to address any potential simultaneity and reverse causation bias, the same estimation is applied to a specification where the lags of all endogenous variables are used instead of their levels. The application of standard within-group panel techniques is, however, not free of problems. It may, in fact, exacerbate measurement errors by removing a significant portion of the variation in the explanatory variables. In addition, it does not address a remaining concern, which is that of cross-sectional dependence.

Following Pesaran (2004) and Baltagi (2005), if such cross-sectional dependence is caused by unobserved common factors which are uncorrelated with the included regressors the standard within-group estimator will still be consistent. However, if the unobserved factors are correlated with the included regressors, the within-group estimator will no longer provide unbiased and consistent results. A solution is the estimation of fixed-effect IVs, provided weak identification of the instruments is not an issue (De Hoyos and Sarafidis, 2006). Therefore, a within-group Two Stage Least Squares (2SLS) model is estimated last, with a varying set of internal instruments. In 2SLS applications, each internal instrument (in this case, endogenous variables' own lags) applies to the full set of endogenous variables, while the exogenous variables (external instruments) are used as instruments for themselves.

\section{Results}

The benchmark regression in equation (1) is estimated in Table 1 in its basic, more parsimonious, form first. Subsequently, all volatility indicators are progressively included in columns (2)-(6). Columns (1)-(7) are within-group estimates, while column (8)-(11) are 2SLS-FE estimates. 
Table 1.

\begin{tabular}{|c|c|c|c|c|c|c|c|c|c|c|c|}
\hline \multicolumn{8}{|c|}{ FE } & \multicolumn{4}{|c|}{ 2SLS-FE } \\
\hline & (1) & (2) & (3) & (4) & (5) & (6) & (7) & (8) & (9) & (10) & (11) \\
\hline LogGDPpc & $\begin{array}{c}-0.262 * * * \\
(0.088)\end{array}$ & $\begin{array}{c}-0.261^{* * *} \\
(0.089)\end{array}$ & $\begin{array}{c}-0.231 * * \\
(0.092)\end{array}$ & $\begin{array}{c}-0.175 * \\
(0.098)\end{array}$ & $\begin{array}{c}-0.321 * * * \\
(0.109)\end{array}$ & $\begin{array}{c}-0.246 * * \\
(0.108)\end{array}$ & $\begin{array}{c}-0.224 * * \\
(0.109)\end{array}$ & $\begin{array}{c}-0.232 * * \\
(0.111)\end{array}$ & $\begin{array}{c}-0.423^{* * *} \\
(0.144)\end{array}$ & $\begin{array}{l}-\mathbf{0 . 2 2 6} * \\
(0.126)\end{array}$ & $\begin{array}{c}-0.359 * * \\
(0.179)\end{array}$ \\
\hline LogGDPpcHI & $\begin{array}{c}0.635 * * * \\
(0.165)\end{array}$ & $\begin{array}{c}0.623 * * * \\
(0.166)\end{array}$ & $\begin{array}{c}0.547 * * * \\
(0.142)\end{array}$ & $\begin{array}{c}0.619 * * * \\
(0.193)\end{array}$ & $\begin{array}{c}0.671 * * * \\
(0.107)\end{array}$ & $\begin{array}{c}0.49 * * * \\
(0.103)\end{array}$ & $\begin{array}{c}0.579 * * * \\
(0.115)\end{array}$ & $\begin{array}{c}0.56^{* * * *} \\
(0.098)\end{array}$ & $\begin{array}{c}0.616^{* * * *} \\
(0.119)\end{array}$ & $\begin{array}{c}\mathbf{0 . 5 3 2} * * * \\
(0.113)\end{array}$ & $\begin{array}{c}0.610 * * * \\
(0.134)\end{array}$ \\
\hline IntRate & $\begin{array}{l}-0.003 * \\
(0.002)\end{array}$ & $\begin{array}{l}-0.003 * \\
(0.002)\end{array}$ & $\begin{array}{c}-0.003 * \\
(0.002)\end{array}$ & $\begin{array}{c}-0.004 * * \\
(0.002)\end{array}$ & $\begin{array}{c}-0.004 * * * \\
(0.001)\end{array}$ & $\begin{array}{c}-0.005^{* * *} \\
(0.001)\end{array}$ & $\begin{array}{c}-0.002 * * \\
(0.001)\end{array}$ & $\begin{array}{l}-0.001 \\
(0.001)\end{array}$ & $\begin{array}{c}-0.005^{* * *} * \\
(0.002)\end{array}$ & $\begin{array}{c}-\mathbf{0 . 0 0 4} * * * \\
(0.001)\end{array}$ & $\begin{array}{c}-0.004 * * * \\
(0.001)\end{array}$ \\
\hline StockMK & $\begin{array}{c}0.151 * * * \\
(0.036)\end{array}$ & $\begin{array}{c}0.154 * * * \\
(0.036)\end{array}$ & $\begin{array}{c}0.152 * * * \\
(0.034)\end{array}$ & $\begin{array}{c}0.124 * * * \\
(0.035)\end{array}$ & $\begin{array}{c}0.133 * * * \\
(0.040)\end{array}$ & $\begin{array}{c}0.144 * * * \\
(0.039)\end{array}$ & $\begin{array}{c}0.12 * * * \\
(0.036)\end{array}$ & $\begin{array}{c}0.118 * * * \\
(0.034)\end{array}$ & $\begin{array}{c}0.113 * * * \\
(0.038)\end{array}$ & $\begin{array}{c}\mathbf{0 . 0 8 8} * * * \\
(0.029)\end{array}$ & $\begin{array}{c}0.090 * * * \\
(0.033)\end{array}$ \\
\hline Balance & $\begin{array}{c}0.004 \\
(0.005)\end{array}$ & $\begin{array}{c}0.004 \\
(0.005)\end{array}$ & $\begin{array}{c}0.005 \\
(0.005)\end{array}$ & $\begin{array}{c}0.003 \\
(0.004)\end{array}$ & $\begin{array}{c}0.003 \\
(0.003)\end{array}$ & $\begin{array}{c}0.006 * * \\
(0.003)\end{array}$ & $\begin{array}{c}0.004 \\
(0.003)\end{array}$ & $\begin{array}{l}0.005^{*} \\
(0.003)\end{array}$ & $\begin{array}{c}0.010 * * * \\
(0.003)\end{array}$ & $\begin{array}{l}\mathbf{0 . 0 0 5} * \\
(0.003)\end{array}$ & $\begin{array}{c}0.009 * * * \\
(0.003)\end{array}$ \\
\hline PropertyRight & $\begin{array}{c}0.002 \\
(0.008)\end{array}$ & $\begin{array}{c}0.002 \\
(0.008)\end{array}$ & $\begin{array}{l}-0.002 \\
(0.008)\end{array}$ & $\begin{array}{c}0.009 \\
(0.012)\end{array}$ & $\begin{array}{c}0.009 \\
(0.010)\end{array}$ & $\begin{array}{c}0.005 \\
(0.010)\end{array}$ & $\begin{array}{l}0.017 * \\
(0.010)\end{array}$ & $\begin{array}{c}0.013 \\
(0.008)\end{array}$ & $\begin{array}{c}0.007 \\
(0.011)\end{array}$ & $\begin{array}{c}\mathbf{0 . 0 1 9} * * \\
(0.009)\end{array}$ & $\begin{array}{l}0.019 * * \\
(0.009)\end{array}$ \\
\hline GoverR\&D & $\begin{array}{c}0.215 \\
(0.189)\end{array}$ & $\begin{array}{c}0.213 \\
(0.190)\end{array}$ & $\begin{array}{c}0.261 \\
(0.181)\end{array}$ & $\begin{array}{c}0.204 \\
(0.222)\end{array}$ & $\begin{array}{c}0.179 \\
(0.150)\end{array}$ & $\begin{array}{c}0.169 \\
(0.139)\end{array}$ & $\begin{array}{c}0.103 \\
(0.092)\end{array}$ & $\begin{array}{c}0.283 \\
(0.175)\end{array}$ & $\begin{array}{l}0.466^{*} \\
(0.246)\end{array}$ & $\begin{array}{c}\mathbf{0 . 1 5 9} \\
(0.180)\end{array}$ & $\begin{array}{c}0.121 \\
(0.155)\end{array}$ \\
\hline TradeOpen & $\begin{array}{c}0.057 \\
(0.069)\end{array}$ & $\begin{array}{c}0.059 \\
(0.069)\end{array}$ & $\begin{array}{c}0.086 \\
(0.069)\end{array}$ & $\begin{array}{c}0.018 \\
(0.065)\end{array}$ & $\begin{array}{c}0.029 \\
(0.079)\end{array}$ & $\begin{array}{c}0.092 \\
(0.075)\end{array}$ & $\begin{array}{c}0.035 \\
(0.065)\end{array}$ & $\begin{array}{c}0.059 \\
(0.096)\end{array}$ & $\begin{array}{c}0.143 \\
(0.166)\end{array}$ & $\begin{array}{c}\mathbf{0 . 0 3 0} \\
(0.098)\end{array}$ & $\begin{array}{c}0.002 \\
(0.098)\end{array}$ \\
\hline StockMKCoV & & $\begin{array}{l}-0.080 * \\
(0.048)\end{array}$ & & & & $\begin{array}{l}-0.040 \\
(0.055)\end{array}$ & $\begin{array}{l}-0.037 \\
(0.054)\end{array}$ & $\begin{array}{c}-0.011 \\
(0.041)\end{array}$ & $\begin{array}{l}-0.011 \\
(0.050)\end{array}$ & $\begin{array}{l}\mathbf{- 0 . 0 2 6} \\
(0.046)\end{array}$ & $\begin{array}{l}-0.057 \\
(0.049)\end{array}$ \\
\hline LogGDPCoV & & & $\begin{array}{c}-0.133 * * \\
(0.054)\end{array}$ & & & $\begin{array}{c}-0.205^{* * *} \\
(0.046)\end{array}$ & $\begin{array}{c}-0.111 * * \\
(0.044)\end{array}$ & $\begin{array}{c}-0.14 * * * \\
(0.037)\end{array}$ & $\begin{array}{c}-0.226 * * * \\
(0.055)\end{array}$ & $\begin{array}{c}-\mathbf{0 . 1 4 2} \\
(0.040 * *\end{array}$ & $\begin{array}{c}-0.125 * * * \\
(0.040)\end{array}$ \\
\hline IntRateCoV & & & & $\begin{array}{c}-0.005^{* *} \\
(0.002)\end{array}$ & & $\begin{array}{c}-0.009 * * * \\
(0.003)\end{array}$ & $\begin{array}{c}-0.009 * * \\
(0.003)\end{array}$ & $\begin{array}{c}-0.008 * * * \\
(0.003)\end{array}$ & $\begin{array}{c}-0.010 * * * \\
(0.003)\end{array}$ & $\begin{array}{c}-\mathbf{0 . 0 1 0} \\
(0.003)\end{array}$ & $\begin{array}{c}-0.009 * * * \\
(0.003)\end{array}$ \\
\hline StateFragility & & & & & $\begin{array}{c}-0.020 * * \\
(0.010)\end{array}$ & $\begin{array}{c}-0.022 * * \\
(0.010)\end{array}$ & $\begin{array}{l}-0.016 * \\
(0.009)\end{array}$ & $\begin{array}{c}-0.017 * \\
(0.009)\end{array}$ & $\begin{array}{c}-0.028 * * \\
(0.011)\end{array}$ & $\begin{array}{c}\mathbf{- 0 . 0 2 3} * * \\
(0.009)\end{array}$ & $\begin{array}{c}-0.026^{* *} \\
(0.010)\end{array}$ \\
\hline Obs. & 398 & 396 & 393 & 343 & 340 & 338 & 294 & 295 & 305 & 284 & 284 \\
\hline $\mathbf{R}^{2}$ & 0.37 & 0.38 & 0.39 & 0.36 & 0.98 & 0.99 & 0.99 & 0.41 & 0.4 & 0.38 & 0.42 \\
\hline N. country & 59 & 59 & 59 & 58 & 57 & 57 & 52 & 46 & 50 & 44 & 44 \\
\hline $\begin{array}{l}\text { Wald F } \\
\text { Hansen J }\end{array}$ & . & . & . & . & . & . & . & 2.8 & 3 & $\begin{array}{c}10 \\
0.13\end{array}$ & $\begin{array}{c}11 \\
0.49\end{array}$ \\
\hline
\end{tabular}

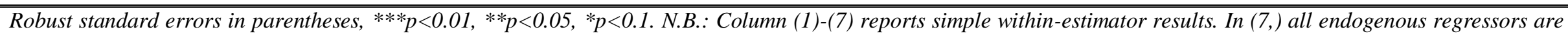

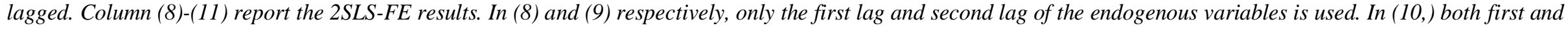
second lags are combined in the set of internal instruments. Column (11) adds year dummies to the specification in (10). 
Huber-White robust standard errors are reported for the whole estimation set. ${ }^{7}$ The most basic regression specification in column (1) only includes (log) GDP per capita and its HI interaction, the lending interest rate, the stock market capitalization measure, public balance, trade openness and public R\&D spending. Both GDP per capita and its interaction term are significant, albeit of opposite sign. This suggests the existence, in my sample, of a threshold level of GDP per capita after which Business R\&D and the level of a development are positively related. Such threshold value of average national GDP per capita occurs, in my sample, at about $\$ 3000$ per year. $^{8}$

The lending interest rate enters with a negative coefficient as expected. The coefficient of stock market capitalisation indicates that more developed financial markets are positively related to the share of R\&D funded by the private sector. The latter result is in line with the findings of Levine and Zervos (1996) in that it enhances capital stock accumulation and its productivity. It is also in line with the finding of Greenwood and Smith (1997) according to which it facilitates technologyintensive investment by lowering the cost of mobilising savings. For the sample considered, all other covariates enter the basic within-group specification with coefficient insignificantly different from zero.

Successively, moving from left to right in columns (2)-(5), the instability measures are added, one at a time and each one separately, and, all enter the regression with a negative sign. This indicates that excessive fluctuations in stock market capitalization rates, in aggregate output, in lending real interest rates and in the political environment all negatively affect private innovative investment. As argued above, such instability is likely to produce a change in firms' incentives and a revision

\footnotetext{
${ }^{7}$ Errors clustered at the country levels have also been used, with no significant difference in the results

8 Note that the World Bank Atlas Classification System defines as lower middle income countries all countries in which average GNI per capita is comprised between the annual value of \$1026-4035
} 
of expected return rates. These findings are in line with those of Barro (1991), Alesina et al. (1996), Fosu (2003) and confirmed by the previously cited microeconometric body of evidence surrounding the impact of volatility on R\&D investment (Rafferty, 2003; Aghion et al., 2008; Rafferty and Funk, 2008; Bohva-Padilla et al., 2009). In column (6), all volatility measures are included in the benchmark specification at the same time. Two relevant changes take place with respect to the previous set of regressions: the change in significance of government balance now indicates that improved fiscal performance is positively related to private innovation spending. In addition, the impact of financial volatility is no longer significant when the other measures of real, monetary and political instability are included in the regression at the same time. This may indicate that when financial volatility appeared on its own its positive coefficient might have been capturing the effect of the other three components of aggregate volatility.

One possible drawback of the results presented thus far is that they may be biased by reverse causation between the dependent variable and the endogenous covariates. To address the source of this simultaneity bias, the specification in column (6) is improved upon in column (7), where all endogenous variables are replaced by their first lag. While all results are substantially very similar to the ones previously presented, something to note is the fact that the measure of property rights protection now enters the model with a positive sign, indicating that in this sample improved rule of law enforcement leads to higher aggregate innovation spending. The result is in line with Yang and Maskus (2001), Varsakelis (2001) and Lin et al. (2010). It should not, however, be seen as a contradiction of the argument that strict IPRs protection might slow the pace of innovation (Helpmann, 1993; Higino Schneider, 2005), because the index of property rights protection used here proxies for a broader spectrum of rule of law enforcement dimensions, such as judiciary fairness and effectiveness. 
A further concern, as anticipated above, is that related to the potential presence of cross-sectional dependence. To address that, as well as to improve upon the treatment of endogeneity in the model, in a within-group 2SLS model is estimated in columns (8)-(11). In column (8), only the first lag is used in the internal instrument set, and in column (9) only the second lag. Both the interest rate and the index of property right protection lose significance in (8), while government balance gains it. All other results carry over from (7). In column (9), again the core results regarding the instability measures only slightly vary in magnitude. The interest rate is once again significant, as is government R\&D expenditure albeit only at the $10 \%$ level. ${ }^{9}$ Neither the results of (8) nor those of (9) can, however, be trusted as the Kleibergen-Paap F statistics is considerably below 10, indicating that the identification of these models is weak. A Hansen $\mathbf{J}$ statistics for the overidentification test is not reported for either because the equations are exactly identified.

To improve upon such shortcomings, in column (10) both sets of lags are combined in the instrumentation strategy. ${ }^{10}$ Once again, results carry over from previous specifications in that the impact of the level of development is overall positive, but the result is driven, in this sample, by middle to high income countries only. In fact, low income levels appear to be marginally detrimental to private innovative investment. As expected, higher interest rate levels discourage Business R\&D in this sample, while more developed stock markets encourage it. Improved fiscal performance is positively related to private $\mathrm{R} \& \mathrm{D}$ spending, and so is improved property rights protection. Neither public R\&D spending nor trade openness have an impact which is significantly different from zero (see David et al., 2000 and Varsakelis, 2001 for similar evidence).

9 Note that, due to the structure of the dataset, using the second rather than the first lag to instrument the endogenous variable results in a higher number of observations. This is due to the fact that some countries only provide innovation spending data, every two years

10 These results appear in bold in the table to indicate that (10) is the preferred benchmark specification. 
With regards to the volatility measures, the coefficient of variation of stock market capitalization once again is not significant when other instability measures are included at the same time. Because this variable has never entered the regression with a non-zero impact, except when estimated on its own, it will dropped from all subsequent robustness tests. Real, monetary and political instability confirm their negative relationship with aggregate private $R \& D$ investment.

These results are qualitatively similar to the ones attained by the previously cited microeconometric literature (Rafferty, 2003; Aghion et al., 2008; Rafferty and Funk, 2008; Bohva-Padilla et al., 2009) with respects to the impacts of real and monetary volatility. In this literature, aggregate demand volatility is proxied by sales, while monetary volatility is proxied by firms' financial constraints. The qualitative impact estimated is, however, broadly comparable. Similarly, with respects to the institutional dimension, my result s in line with Barro (1991), Alesina et al. (1996), Fosu (2003), and Rodrik (1989). In particular, it conforms to the argument put forward by Rodrik, which shows that investors' expectations are based on the subjective probability attached to policy reversal and on the magnitude of investment irreversibility. ${ }^{11}$ It follows that when both are high, aggregate private $R \& D$ investment will decline.

In order to provide a quantitative interpretation of the coefficient magnitude for the instability indicators, it may be useful to refer to the summary statistics table (below). The real volatility coefficient reported in column (10) of Table 1, can be interpreted in percentage change terms (see Appendix $\mathrm{B}$ for details). It indicates that, in this sample, a $1 \%$ increase in the coefficient of variation of $(\log )$ GDP per capita, leads to a $0.142 \%$ point decrease in private R\&D spending. If we

11 Goel and Ram (1999) show that the impact of uncertainty is larger on R\&D investment, because of its high irreversibility. This irreversibility is due to the fact that a large share of $R \& D$ investment goes into project-specific personnel and equipment. 
evaluate this impact at the mean value of the Business R\&D to GDP ratio, it is immediately evident that this is a rather sizable impact. In fact, Table 2 shows that the average share of Business R\&D to GDP in this sample is of around $0.71 \%$.

Table 2. Summary Statistics

\begin{tabular}{lcccc}
\hline \hline VARIABLE & MEAN & ST. DEV. & MIN & MAX \\
\hline BusinessR\&D & 0.709 & 0.714 & 0.0007 & 3.402 \\
GoverR\&D & 0.465 & 0.238 & 0.02 & 1.054 \\
LogGDPpc & 9.016 & 1.109 & 5.645 & 10.55 \\
LogGDPpcHI & 9.562 & 0.662 & 7.973 & 10.55 \\
IntRate & 6.082 & 6.433 & 0 & 43.8 \\
StockMK & 0.624 & 0.58 & 0.006 & 3.084 \\
PropertyRight & 6.79 & 1.565 & 1.599 & 10 \\
Balance & -1.34 & 3.101 & -12.67 & 11.37 \\
TradeOpen & 0.97 & 0.626 & 0.234 & 4.381 \\
StateFragility & 3.214 & 4.058 & 0 & 16 \\
LogGDPCoV & 0.324 & 0.241 & 0.009 & 1.271 \\
IntRateCoV & 0.531 & 1.148 & 0.0005 & 11.74 \\
StockMKCoV & 0.12 & 0.0007 & 0.813 \\
ExchRate & 0.14 & 0.298 & 9170 \\
ExchRateCoV & 189.7 & 746.3 & 0 & 1.38 \\
LogGDPStDev & 0.082 & 0.186 & 0.0009 & 0.094 \\
IntRateStDev & 0.029 & 0.019 & 0.374 & 41.84 \\
PolConstraint & 2.689 & 4.014 & 0 & 0.718 \\
Democracy & 0.447 & 0.142 & -7 & 10 \\
HtExp & 8.641 & 3.116 & 0.513 & 73.59 \\
TaxRevenue & 16.61 & 14.7 & 0.957 & 33.19 \\
FinancialDev & 18.07 & 0.033 & 0 & 2.024 \\
FinancialDevCoV & 0.929 & 0.381 & 0.266 \\
\hline \hline
\end{tabular}

Moving to the impact of monetary volatility: in this sample, a one standard deviation increase in the coefficient of variation of the interest rate results in $0.01 \%$ point decrease in private R\&D. Considering that the minimum sample value of Business R\&D as a share of GDP is equal to $0.0007 \%$, the impact of monetary volatility is again not trivial. Finally, a 1 point increase in the 'State Fragility' Index (which ranges from 0 to 25 ) leads to a $0.023 \%$ point decrease in aggregate Business R\&D spending. 
The instrumentation validity for the benchmark specification is confirmed by the F-stat and Hansen J statistics of column (10), which indicate that the regression is robustly identified. Finally, in column (11), year dummies are added. While they do not alter any of the finding presented so far, none is significant, therefore they will be dropped from any subsequent estimation.

\section{ROBUSTNESS ANALYSIS}

In the following section, I investigate the robustness of the findings reported so far, by reestimating the benchmark regression under various modifications. These include alternative measurements of instability, variations in the regression specification, the inclusion of non-linear effects, and the inclusion of additional right hand side variables. It will be shown, however, that the basic findings are not affected by such robustness tests.

To start with, the impact of volatility on investment has been suggested in the literature to exhibit threshold effects. Sarkar (2000), in particular, argued that a positive relationship occurs at low uncertainty levels, and that this switches to a negative relationship only when uncertainty rises beyond a critical threshold. To test this hypothesis, non-linearity effects have been modeled into the benchmark specification, first, with the inclusion of quadratic terms in column (2), and secondly, in column (3), with the inclusion of interaction terms. Column (1) of Table 3 (below) repeats the benchmark specification to facilitate comparison. ${ }^{12}$ In column (2), quadratic terms for both real and monetary volatility are included, which indicate that as either volatility dimension increases, aggregate private R\&D spending decreases at an increasing rate. ${ }^{13}$ Thus, unlike Sarkar, I find that

12 Note that the volatility of stock market capitalisation is not reported, because, due to its insignificance throughout the estimation set of Table 2, the measure has been dropped from all subsequent robustness tests.

13 Note that a quadratic term of the StateFragility index is not included due to the ordinal nature of this variable 
Table 3.

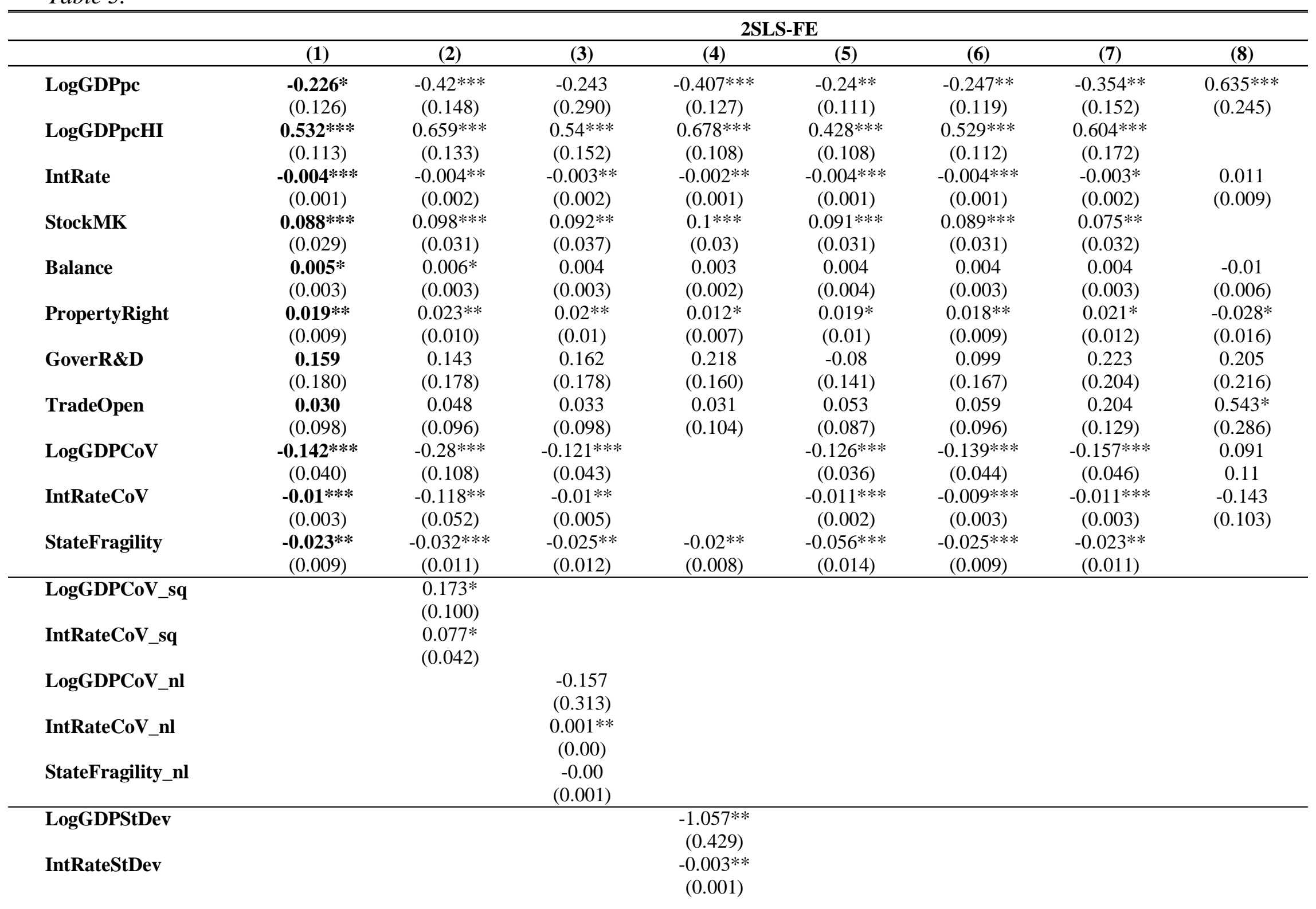




\section{PolConstraint}

ExchRate

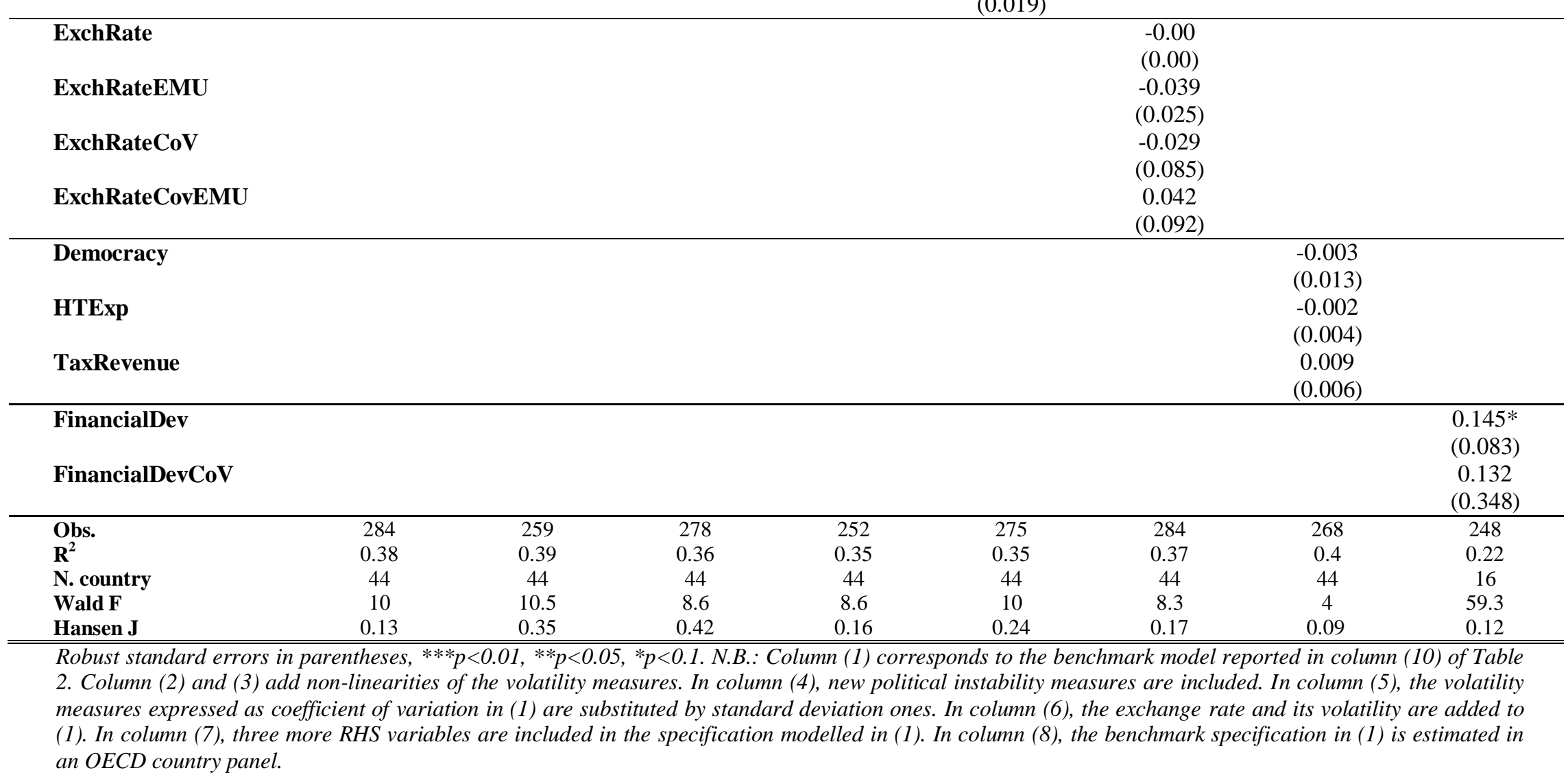


the impact of volatility on this type of private investment is negative, and increasingly so for higher values of volatility. The rest of the results in this regression carry over from previous specifications. In column (3), another type of non-linearity is examined. Specifically, I test whether the impact of instability varies according to the phase of the business cycle. To do this, I create a measure of GDP deviation from its mean, ${ }^{14}$ and interact it with each volatility indicator. The interaction terms will indicate whether any difference exists between the impact of volatility during a recession and its impact during an expansion. My results indicate that a discernible differential in impact only exists for the monetary volatility component.

In particular, my results indicate that, as the phase of the cycle improves, volatility in the interest rate becomes less of a hindrance to private $R \& D$ spending. This result is line with the claim made by the body of microeconometric literature reported above that uncertainty has less of a negative effect when credit constraint are not as binding (Aghion and Saint Paul, 1998; Rafferty and Funk, 2008; Aghion et al., 2008; Bohva-Padilla et al., 2009). If such 'credit constraint' effect is the prevailing dynamic underlying different investment responses along the business cycle, then this may account for the failure to identify a similar impact in the case of real and political instability. Moreover, uncertainty in GDP per capita and state effectiveness levels is less observable than fluctuations in the official lending interest rate. For this reason, the aggregate spending adjustment to real or political instability may be not as correlated or synchronised to the phase of the cycle as it is the case of interest rate variations. No other change takes place with regards to all other results.

Next, in column (4) and (5), I test the robustness of the volatility impacts uncovered so far to variations in the way instability is measured, or variations in the channel through which the impact

14 The mean of (log) GDP per capita is calculated across the entire 1994-2008 time window. For each country, this is then subtracted from each year's realised (log) GDP per capita value 
takes place. In particular, in column (4), I use the standard deviation of both (log) GDP per capita and interest rate instead of their coefficient of variation. A great part of the literature agrees on the coefficient of variation being a more robust indicator of volatility than the standard deviation. Mobarak (2005) and Klomp and de Haan (2009) argue that the latter is an absolute measure of variation and it is very sensitive to noise in the data. The normalisation involved in the coefficient of variation, instead, makes it a relative measure of variation. In this respect, Klomp and de Haan (2009) show that the coefficient of variation allows to appropriately control for co-movements of similar countries, due, for example, to the effect of common business cycle patterns. Nonetheless, some shortcomings still persist in this measure. For example, for mean values close to zero, the coefficient of variation will approach infinity and be sensitive to small changes in the mean.

Therefore, the robustness of the findings based on the coefficient of variation measures will be tested against those obtained using the standard deviation. All basic results remain identical in column (4)'s specification. Real and monetary instability keep the same qualitative impact, though the coefficient magnitudes need re-interpreting. In this sample, the coefficient of real volatility indicates that a one standard deviation increase in (log) GDP per capita leads to a $1.057 \%$ points decrease in Business $R \& D$; while an increase in one standard deviation of the real interest rate leads to a decrease of $0.003 \%$ point.

In column (5), I verify the robustness of the institutional instability indicator by adding a measure of political constraints and an interaction between state fragility and political constraints. This is done in order to test under what specific conditions institutional instability produces negative changes in the level of aggregate private innovation spending. In particular, Henisz (2002) has constructed and used the 'Political Constraint' variable to show that constraints on the ease of policy shifts in any given country are conducive to infrastructural investment, and specifically to 
innovative investment. The index scores are derived from a simple spatial model and theoretically range from 0 to 1 , with higher scores indicating more political constraint and thus less feasibility of policy change. The idea is that, when any political actor can easily influence policy change, the resulting institutional framework will be more unstable. The political constraint measure is included in the model together with StateFragility and an interaction between the two. The impact of state fragility remains negative; however its magnitude has now increased. Unlike Henisz (2002), higher political constraints appear to hinder private R\&D spending in this sample. This seemingly contradictory result can however be reconciled if one considers that a slow pace of policy change is negatively correlated to innovation when the former proxies for a conservative societal structure, or a malfunctioning National System of Innovation (see Lundvall, 1992, for more details on this point in the context of the National Innovation System literature). On the other hand, however, the interaction term between institutional instability and the political constraints index has a positive sign. This indicates that, given a negative impact of state fragility on business innovation, increased political constraints mitigate such negative impact, by limiting the extent to which instability can produce abrupt policy shift.

Column (6) and (7) carry out some further robustness checks, via the inclusion of additional right hand side variables. As pointed out by Serven (2003), fluctuations in the nominal exchange rate can affect the export/import incentives of firms. In column (6), this international dimension is brought into the picture by adding the exchange rate level among the explanatory variables. At the same time, the coefficient of variation of the official exchange rate is also included to control for the effect of recurrent fluctuations in its level. Two additional terms are also constructed, by interacting a dummy variable $(E M U)$, with both the exchange rate level and its volatility. $E M U$ takes the value of 1 for those countries which joined the European Monetary Union (EMU), and only in the year they switched currency regime. 
When the exchange rate is interacted with $E M U$, the interaction term controls for the structural break taking place when the euro currency regime is adopted, by correcting for the switch in measurement units. ${ }^{15}$ Instead, the interaction term between the volatility of the exchange rate and $E M U$ is used to capture the increased exchange rate stability which followed the adoption of the common currency by the Euro Zone economies. While all previous results remain identical, none of the four variables introduced to model the international dimension enters the regression significantl. While this result contradicts Serven (2003), it is not an uncommon finding in the literature. In fact, the evidence on the relationship between exchange rate regimes and firms' exports is rather inconclusive (see Wang and Barrett, 2007, for a review).

Moving now to column (7) of Table 3, I present the set of results deriving from the inclusion of a number of additional regressors. Democracy takes values from 10 (very democratic countries) to 0 (autocratic regimes). HTExp refers to the amount of high-tech exports to GDP and it has been instrumented with its first and second lag to account for its likely endogeneity. TaxRevenue refers to the level of overall fiscal imposition to GDP. None of these variables enters the regression significantly, but once again, neither the significance nor the qualitative impact of all other variables has been altered by the inclusion of these new covariates. Note, however, that both the Fstat and the Hansen-J statistic deteriorate sharply in this specification. Such change is attributable to the inclusion of HTExp among the endogenous variables and of its lags in the instrumentation set, which has weakened the identification strategy.

\footnotetext{
${ }^{15}$ Most EMU countries in my sample joined the currency union in 1999; the rest between 2001 and 2007. When the switch takes place, LCU denominated exchange rates turn to euro denominations. The EMU dummy takes into account the break to avoid biasing the estimation.
} 
In the last robustness test, carried out in column (8), I restrict the estimation sample to OECD countries only. This is done, first of all, because instability levels can be expected to be lower in these countries during the time span considered. At the same, a larger proportion of firms in highincome countries is likely to exhibit lower financial constraints and to have access to better developed financial markets. The combination of all such factors may result in an improved ability of the private sector to cope with volatility. ${ }^{16}$ Thanks to the wider data coverage, the reduced panel is formed by fewer countries (17) but it covers a longer time period of 28 years, from 1981 to 2008 , with a total sample size of 246 observations.

The results shown in column (8) lend some support to the hypothesis mentioned above. In fact, in this sample, the evidence on the impact of real, monetary, political and financial instability is inconclusive. ${ }^{17}$ On the other hand, both the level of aggregate GDP per capita and the level of financial development are positive predictors of private $R \& D$ spending. ${ }^{18}$ In addition, trade openness also appears to have a positive impact on Business R\&D in this sample, (significant at the $10 \%$ level). This result is in line with the theoretical (Porter, 1990; Lundvall, 1992; Nelson, 1993) and empirical findings (Smolny, 2003; Sameti et al., 2010; Wang, 2010) of a number of studies, which show how international openness is likely to result in a positive impact on technological progress, due to increased external exposure and interaction. Finally, an interesting finding of this specification is the negative relationship linking Business $R \& D$ to the index of property rights protection. However, this result should not be seen as surprising, given that the protection standards

16 Or even in its capacity to benefit from such fluctuations. As put forward by Schumpeter-inspired creative destruction theories (Hall, 1991; Saint-Paul, 1993).

17 Note that the 'StateFragility' measure could not be used in this sample due to its time coverage (earliest data period is 1994). Therefore Henisz's Political Constraint Index is used instead

18 Note that, in this sample, due to the data availability restrictions for the 1980s, stock market capitalisation has been substituted by a measure of private credit by commercial banks as a proxy for financial development 
of both physical and intellectual property rights enforced in this sample of OECD economies is already very high. The result may rather indicate that there exists a certain threshold past which stricter enforcement levels can prove detrimental to innovation incentives and diffusion. Such argument is supported by various theoretical and empirical studies (Furukawa, 2007; Murray and Stern, 2007; Bessen and Maskin, 2009; Gangopadhyaya and Mondal, 2012), which show that the relationship between property rights protection and innovation exhibits an inverted-U pattern, in which too weak or too high enforcement levels are detrimental to the pace of innovation.

\section{CONCLuSiONS}

This paper has studied the impact of macro-institutional instability on private innovative investment. The underlying motivation for investigating such relationship lies in the consideration that innovation is crucial to growth and development. Yet, its long maturity horizon coupled with its high-budget nature make it an intrinsically riskier type of investment. The empirical analysis has therefore sought to clarify the relationship between various dimensions of volatility and aggregate private $R \& D$ spending in unstable macro-institutional environments.

The contribution of the paper has been threefold. Firstly, the literature on the impact of instability on private $R \& D$ spending focuses mainly on first moment effects, by relating recessions to innovation incentives. Such focus has been here expanded to cover second moment fluctuations, that is, it has been extended to the role of overall volatility. Secondly, a macroeconometric approach has been adopted to complement the firm-based evidence already available in the literature. While such approach has its limitation, it has helped uncover the aggregate dynamics underlying movements in national levels of private $\mathrm{R} \& \mathrm{D}$ investment in unstable environments. 
Finally, the analysis has disentangled the specific impact of a number of co-existing instability dimensions. In particular, the econometric findings suggested three channels through which macroinstitutional volatility negatively affects business $R \& D$ investment, that is, political, real and monetary volatility. Such impact has been shown to exhibit non-linearities and to be larger for higher values of the real and monetary volatility dimensions. In addition, the negative effect of monetary instability appears to be mitigated during expansionary phases of the cycle, in the sample considered. Finally, the evidence on financial and international volatility is inconclusive.

The indirect policy implication deriving from the results here presented points towards the desirability of safeguarding stable macroeconomic and institutional environments if encouraging private innovation engagement is a priority. Considerations regarding the most appropriate policy tools are beyond the scope of this paper. However, an interesting avenue for further research seems to be the investigation of the role that targeted counter-cyclical policy interventions may play in preserving private profitability horizons and incentives. 


\section{APPENDIX A: DATA AND COUNTRY APPENDIX}

TABLE A1. DATA SOURCES

$\begin{array}{ll}\text { BUSINESSR\&D } & \text { R\&D spending by the private sector (\%GDP) } \\ \text { GOVERR\&D } & \text { R\&D spending by the public sector (\%GDP) } \\ \text { LOGGDPPC } & \text { Log(Total Output / Population) } \\ \text { INTRATE } & \begin{array}{l}\text { Lending Interest Rate charged to businesses by } \\ \text { commercial banks, with maturity of } 3 \text { months to } 1 \\ \text { year, minus the Inflation Rate }\end{array} \\ \text { BALANCE } & \text { Overall Deficit/Surlpus (\%GDP) }\end{array}$

TradeOpen

Property Right

SтоскMK

StateFragility

PolConstraint

EXChRATE

DEMOCRACY

HTEXPORTS

TAXREVEnUE

FinANCIALDEV
(Exports + Imports) / GDP

0-10 Index where 10 indicates the highest level of rule of law enforcement

Value of listed shares to GDP, calculated using the deflation: $\left\{(0.5) *\left[\mathrm{~F}_{\mathrm{t}} / \mathrm{P}_{\mathrm{et}}+\mathrm{F}_{\mathrm{t}-1} / \mathrm{P}_{\mathrm{et}-1}\right]\right\} /\left(\mathrm{GDP}_{\mathrm{t}} / \mathrm{P}_{\mathrm{at}}\right)$, where $\mathrm{F}$ is stock market capitalization, $\mathrm{P}_{\mathrm{e}}$ is end-of period CPI, and $\mathrm{P}_{\mathrm{a}}$ is average annual CPI

The Index scores countries on effectiveness and legitimacy in four dimensions: security, political, economic, and social. Scores are 0-25 where 0 indicates very stable countries

The index measures the feasibility of policy change It ranges from $0-1$, with higher scores indicating more political constraint

Nominal Exchange Rate (LCU per US\$)

The index ranges from -10 to 10 , where -10 is the score given to authoritarian regimes

High-Tech Exports/ Tot Manufacturing Exp

Tot Tax Revenue / GDP

Private credit by deposit money banks and other financial institutions to GDP, calculated using the deflation: $\left\{(0.5) *\left[\mathrm{~F}_{\mathrm{t}} / \mathrm{P}_{\mathrm{et}}+\mathrm{F}_{\mathrm{t}-1} / \mathrm{P}_{\mathrm{et}-1}\right]\right\} /\left(\mathrm{GDP}_{\mathrm{t}} / \mathrm{P}_{\mathrm{at}}\right)$ where $\mathrm{F}$ is stock market capitalization, $\mathrm{P}_{\mathrm{e}}$ is end-of period $\mathrm{CPI}$, and $\mathrm{P}_{\mathrm{a}}$ is average annual CPI
OECD-MSTI Database
UNESCO - Stats.uis
RICYT.org

OECD-MSTI Database

UNESCO - Stats.uis

RICYT.org

World Bank-WDI

Own calculation

Data on lending interest rate and CPI is from World Bank-WDI

IMF -Government Finance Statistics

World Bank-WDI

Economic Freedom of the World - Area 2: Legal System and Property Rights

Database on Financial Development and Structure (Beck et al. 2009)

POLITY IV Dataset

Henisz' Political Constraints Index III Dataset

World Bank-WDI

IMF-International Financial Statistics

POLITY IV Dataset

World Bank-WDI

IMF- Governance Finance Statistics

Database on Financial Development and Structure (Beck et al. 2009) 


\begin{tabular}{|c|c|c|c|c|}
\hline Argentina & Cyprus* & Ireland*† & Mongolia & Slovak Rep* \\
\hline Australia $\uparrow$ & Czech Rep* & Israel $* \dagger$ & Netherlands $* \dagger$ & Slovenia* \\
\hline Austria*† & Denmark $*^{*}$ & Italy*† & Norway $\dagger$ & South Africa \\
\hline Belgium*† & Estonia* & Japan $\dagger$ & Panama & Spain** \\
\hline Bolivia & Finland $* \dagger$ & Korea Rep*† & Paraguay & Thailand \\
\hline Brazil & France** & Kuwait & Philippines & Uganda \\
\hline Bulgaria & Germany*† & Latvia* & Poland* & Ukraine \\
\hline Canada*† & Hungary* & Lithuania & Portugal $* \dagger$ & United Kingdom*十 \\
\hline Chile & Iceland $* \dagger$ & Malaysia & Romania & United States*† \\
\hline China & India & Malta* & Russia & Uruguay \\
\hline Colombia & Iran & Mexico & Singapore* & Venezuela \\
\hline
\end{tabular}

*High-Income countries (ATLAS classification) *†OECD countries included in the robustness analysis panel $† \mathrm{OECD}$ countries appearing in the robustness analysis panel only

\section{APPENDIX B: TECHNICAL APPENDIX}

The Coefficient of Variation is a normalized measure of dispersion of a variable's distribution over a certain time period. It is calculated as the ratio of the standard deviation to the mean of a series.

$$
v=(\sigma / \mu)
$$

where the standard deviation is calculated as follows

$$
\sigma=\sqrt{\frac{1}{N-1} \sum_{i=1}^{N}\left(x_{i}-\bar{x}\right)^{2}}
$$

In this paper, a two year rolling window is utilised to calculate both mean and standard deviation of (logged) GDP per capita, real interest rate and stock market capitalisation. Thus real, monetary and financial volatility, in this context, is defined as the ratio of the standard deviation to the mean of the rolling window. A backward looking strategy has been used in constructing such window, to 
reflect the type of knowledge agents might have of volatility at time $t$. The latter is typically attained by comparing the volatility levels prevailed at time $t-1$ with those of time $t$. For example, to obtain the real volatility of the year 2001, the standard deviation and mean of (log) GDP per capita are first calculated over the 2000-2001 period and then their ratio is multiplied by 100 . Likewise, to obtain the coefficient of variation of GDP per capita in 2002, values from the years 2001 and 2002 are used to calculate both standard deviation and mean. Please note that, because of the log transformation with which GDP per capita appears in the regressions, the coefficient magnitude of real volatility is not comparable to that of the other volatility measures. To restore visual comparability, the coefficient of variation of GDP per capita has been multiplied by 100. Its quantitative interpretation will however also be in percentage change terms.

\section{REFERENCES}

Abel, A.B. (1983) “Optimal Investment under Uncertainty”. American Economic Review, 73, 228-33.

Acemoglu,D. and Zilibotti, F.(2001) 'Productivity Differences' Quarterly Journal of Economics,116:563-606 Agenor, P. and Neanidis, K. (2011) 'Innovation, Public Capital and Growth' University of ManchesterCGBCR Series

Aghion, P., Angeletos, G., Banerjee, A. and Manova, K. (2010) "Volatility and Growth: Credit Constraints and the Composition of Investment" Journal of Monetary Economics, vol. 57(3), pp.246-265

Aghion, P., Askenazy, P., Berman, N., Cette, G., Eymard, L.(2008) 'Credit Constraints and the Cyclicality of R\&D Investment: Evidence from France' Journal of the European Economic Association, 10(5), 1001-1024

Aghion, P. And Saint-Paul, G. (1998) "Virtues of Bad Times, Interactions between Productivity Growth and Economic Fluctuations" Macroeconomic Dynamics, 2, 322-344

Alesina, A., Ozler, S., Roubini, N., Swagel, P. (1996) "Political Instability and Economic Growth". Journal of Economic June. 1:189-211.

Baltagi, B., (2005) "Econometric Analysis of Panel Data". 3rd ed. New York: Wiley.

Barrett, C., Sherlund, S. and Adesina, A. (2006) "Macroeconomic Shocks, Human Capital and Productive Efficiency: Evidence from West African Rice Farmers”. Journal of African Economies, 15(3), 343-72. 
Barro, R. (1991) 'Economic Growth in a Cross Section of Countries' Quarterly Journal of Economics, 106, 407- 43.

Becker, B. and Pain, N. (2008) 'What Determines Industrial R\&D Investment in UK?' The Manchester School, 76, (1), 66-87

Bessen, J. and Maskin, E. (2009). 'Sequential innovation, patents, and imitation' Rand Journal of Economics, $40(4), 611-635$

Bohva-Padilla, S., Damijan, J.P. and Konings, J. (2009) "Financial Constraints and the Cyclicality of R\&D Investment: Evidence from Slovenia". KU Leuven, LICOS - Discussion paper series 239, 1-17.

Bose, N.; Holman, G., and Neanidis, K. (2007) 'The Optimal Public Expenditure Financing Policy: does the Level of Economic Development Matter?’ Economic Inquiry, 45(3), 433-452

David, P.; Hall, B.; Toole, A. (2000). 'Is public R\&D a complement or substitute for private R\&D? A review of the econometric evidence' Research Policy, 29: 497:529

De Hoyos, R. and Sarafidis, V. (2006) "Testing for cross-sectional dependence in panel-data models". The Stata Journal, vol 6(4), 482-496

Dehn, J. (2000). Private Investment in Developing Countries: The Effects of Commodity Shocks and Uncertainty. CSAE Working Paper Series, University of Oxford.

Escaleras, M. and Thomakos, D. (2008) "Exchange Rate Uncertainty, Sociopolitical Instability and Private Investment: Empirical Evidence from Latin America". Review of Development Economics, 12 (2), 372-385.

Fisher,S.(1993) 'The role of macroeconomic factors in growth' Journal of Monetary Economics, 32:485-512.

Fosu, A. (1992) "Political Instability and Economic Growth: Evidence from Sub-Saharan Africa". Economic Development and Cultural Change, 829-841

Fosu, A. (2003) "Political Instability and Export Performance in Sub-Saharan Africa". The Journal of Development Studies, 39(4), 68-82

Furukawa, Y. (2010) 'Intellectual property protection and innovation: an inverted-U relationship' Economics Letters, 109 (2), 99-101.

Gangopadhyaya, K. Mondal, D. (2012). 'Does stronger protection of intellectual property stimulate innovation?' Economics Letters, 116:80-82

Greenwood, J. and Smith, B. (1997) 'Financial markets in development, and the development of financial markets'. Journal of Economic Dynamics and Controls, 21:145-181

Goel, R. and Ram, R. (1999) "Variations in the Effect of Uncertainty on Different Types of Investment: An Empirical Investigation”. Australian Economic Papers 38, 481-492.

Hall, R. (1991). "Recession as Reorganization”. NBER Macroeconomics Annual, Stanford.edu.

Hartman, R. (1972) 'The Effects of Price and Cost Uncertainty on Investment' Journal of Economic Theory, 5:258-266

Henisz, W. (2002). 'The institutional environment for infrastructure investment'. Industrial and Corporate Change, 11(2), 355-89. 
Higino Schneider, P. (2005) 'International trade, economic growth and intellectual property rights: A panel data study of developed and developing countries' Journal of Development Economics, 78:529-547

Grossman, G.M. and Helpman, E. (1993). 'Innovation and Growth in the Global Economy'. MIT Press

Katz J. (1987) “Technology Generation in Latin American Manufacturing Industries”. The Macmillan Press.

Klomp, J. and de Haan, J. (2009) "Political Institutions and Economic Volatility". European Journal of Political Economy, 25, 311-326

Levine, R. and Zervos, S. (1996) 'Stock Market Development and Long-Run Growth' The World Bank Economic Review, 10(2), 323-339

Lin, C.; Lin, P.; and Song, F. (2010). 'Property rights protection and corporate R\&D: Evidence from China' Journal of Development Economics, 93:49-62

Lucas, R. (1988) “On the Mechanics of Economic Development”. Journal of Monetary Economics, 22, 3-42.

Lundvall, B-A. (1992) "National Systems of Innovation: Towards a Theory of Innovation and Interactive Learning". London: Pinter Publishers.

Mankiw, G., Romer, D., Weil D. ( 1992) “A Contribution to the Empirics of Economic Growth”. Quarterly Journal of Economics, 107, 407-437.

Mobarak, A. (2005) "Democracy, Volatility and Economic Development". The Review of Economics and Statistics, 87(2), 348-361.

Murray, F., and Stern, S. (2007) 'Do formal intellectual property rights hinder the free flow of scientific knowledge? An empirical test of the anti-commons hypothesis' Journal of Economic Behavior and Organization, 63, 648-687

Neanidis, K.and Savva, C. (2010) 'Macroeconomic Uncertainty, Inflation and Growth: Regime - dependent Effects in the G7'. Journal of Macroeconomics, 35, 81-92

Nelson, R. (1993) "National Innovation Systems. A Comparative Analysis". Oxford University Press.

Pesaran, M. (2004) "General diagnostic tests for cross section dependence in panels" CESifo WPS No. 1229

Pindyck, R. and Solimano, A. (1993) “Economic Instability and Aggregate Investment”. NBER WPS 4380.

Porter, M. (1990) “The Competitive Advantage of Nations”. Free Press, New York, 1990.

Rafferty, M. (2003). "Do business cycles influence long-run growth? The effect of aggregate demand on firm financed R\&D expenditures". Eastern Economic Journal, 29, (4) 617-618.

Rafferty, M. and Funk, M. (2008) "Asymmetric Effects of the Business Cycle on Firm-Financed R\&D". Econ. Innov. New Techn., 17(5), 497-510.

Romer, P. (1990). ‘Endogenous Technological Change’ Journal of Political Economy, 98(5)

Rodrik, D. (1989) "Policy Uncertainty and Private Investment in Developing Countries". Journal of Development Economics, 36(2), 229-242

Saint-Paul, G. (1993) 'Productivity Growth and the Structure and of the Business Cycle' European Economic Review, 37:861-90. 
Sameti, M., Ranjbar, H., Anoushesh, S. (2010) "Determinants of R\&D Investment: Evidence from OECD countries". The Knowledge Economy, (3), 35-42.

Sarkar, S. (2000) 'On the investment-uncertainty relationship in a real options model' Journal of Economic Dynamics and Controls, 24(2), 219-225

Serven, L. (2003) 'Real-Exchange-Rate Uncertainty and Private Investment in LDCs' The Review of Economics and Statistics, 85(1), 212-218.

Smolny, W. (2003) "Determinants of Innovation Behavior and Investment Estimates for West German Manufacturing Firms”. Econ. Innov. New Techn., 2003, 12(5), 449-463.

Varsakelis, N. (2001). 'The impact of patent protection, economy openness and national culture on R\&D investment: a cross-country empirical investigation'. Research Policy, 30, 1059-1068

Wang, E. (2010) 'Determinants of R\&D Investment: The Extreme-Bounds-Analysis approach applied to 26 OECD countries' Research Policy, 39 (1), 103-116

Wang, K. and Barrett, C. (2007) "Estimating the Effects of Exchange Rate Volatility on Exports Volumes". Journal of Agricultural and Resource Economics, 32(2), 225-255.

Yang, G. and Maskus, K. (2001) 'Intellectual property rights and licensing: An econometric investigation' Review of World Economics, 137(1), 58-79 